\title{
ASSESSMENT OF AVAILABILITY OF THE INTERNAL MARKETING ELEMENTS AT FACULTY OF NURSING
}

\author{
${ }^{1}$ Ali Daifallah A. Abo Soliman, ${ }^{2}$ Prof. Neamat Mohamed El-sayed ${ }^{3}$ Prof. Sanaa Abd \\ El-azeem Ibrahim ${ }^{4}$ Dr. Rasha Ibrahim El-sayed Inany. \\ ${ }^{1}$ M.Sc. in Nursing Administration, Faculty of Nursing, kafr El-sheikh University. ${ }^{2}$ Professor \\ of Nursing Administration, Faculty of Nursing, Damanhur University. ${ }^{3}$ Professor of Nursing \\ Administration, Faculty of Nursing, Port Said University. ${ }^{4}$ Lecturer of Nursing \\ Administration, Faculty of Nursing, Port Said University
}

\begin{abstract}
Background: The aim of this study was to assess the availability of internal marketing elements among internal customers of the Faculty of Nursing, Port Said University. Sample: the study was carried on all available internal customers of the faculty $(n=378)$. Research design A descriptive research design was utilized. Data collection tools: data are collected using three tools: to assess the availability of internal marketing elements for teaching staff, employees and nursing students.Results: revealed that the most available element of the internal marketing among teaching staff, employees and students is the communication element $(76.5 \%, 69.1 \%, 72.1 \%$ retrospectively), followed by supervision $(75.1 \%)$ and scientific research support among teaching staff(73.2\%), supervision and safety measures among employees (67\%) and supervision and achievement and rewards among students (70.7\%). Whereas, the lowest available element is the benefits among teaching staff, employees and students (52.5\%, 43.5\%,68.2\% retrospectively). Conclusion: availability of internal marketing elements at the faculty is moderately fulfilled. The highest mean score of it were among the teaching staff $(70.6 \%)$ followed by students(69.5\%) and employees (62.3\%). Recommendations: The study recommended that academic managers have to develop an internal marketing strategy for Faculty of Nursing at Port Said University.
\end{abstract}

Key words: Internal marketing, internal customer, teaching staff, students, employees. 


\section{INTRODUCTION}

Customer Satisfaction is the most important gadget which makes an organization survive and face the competition. The customers are first key persons who give the business but the internal customers are the pillars who make the business grow and prosperous (Varun \& Indu, 2015).The higher education looked at importance of human capital as one that can produce graduates who have the skills and competency useful both for individual and community. In the global competition is not just how to recruit students but also how to get lecturers who have the competencies that meet the law on teachers and lecturers (Susanti et al., 2015). It is clear that any sustainable competitive advantage for universities is via the staff (Shima \& George, 2014), and in organization they have been called internal marketing (Falavarjani et al., 2013).

Internal marketing concept ( IM ) came into existence nearly two decades ago in the academic arena, since the authors were viewed the internal marketing as a comprehensive tool to achieve customer satisfaction (Minar, Sarwari \& Salam, 2008). Berry (1981) pioneered the term internal marketing and defined it as viewing employees and working staff as internal customers, and viewing jobs as internal products that satisfy the needs and wants of these internal customers while addressing the objectives of the organizations. While Kokemuller (2015) defined internal marketing as the way an organization promotes its values and brand internally to employees that help generate its brand value.

The goal of internal marketing is focusing attention of employees on those internal activities that need to be developed, maintained and improved for the purpose of organization performance and strengthening the organization in external market. Internal marketing is based on seeing employees as internal customers, activities and work tasks are seen as internal products aimed at offering internal products that meet needs and desires of internal and external customers to achieve organization objectives (Paliaga \& Strunje, 2011).Internal marketing creates an environment that enables organizations to focus on whatever needs changing internally so they can enhance their external marketplace performance; internal marketing helps organizations deliver better customer service by aligning, coordinating, and motivating employees (Fogel, 2016). Internal marketing as having resultant effects on three major areas or components: understanding of organizational vision and values, quality delivery of external marketing as well as quality delivery of interactive marketing (Ogunnaike et al., 2012). 
Placing and treating the internal customers ahead of customers is a key to attain better service quality and hence enhanced customer satisfaction with the latter leading to customer loyalty and eventually repeated purchase intention (Byju, 2013). IM does not only affect internal service quality, but also it retains the best internal customers, rewards systems, supporting and develops internal customer' skills (Hashem \& AL-nsour, 2012).Internal marketing elements include the following: senior leadership and management; organizational supervision; organizational and management support; training, advancement and performance appraisal; organizational communication and coordination; empowerment; job description; strategic rewards and incentive systems; safety measures and job security (Galpin, 1997; Hogg, Carter \& Dunne, 1998); Lings, 2000; Conduit \& Mavondo, 2001).

\section{Senior leadership and management:}

Contribution of IM towards more effective implementation of organizational directives and strategies, acknowledging inability of bureaucratic structures to intrinsically motivate and leverage non-controllable aspects of individual employee performance (Boukis, Kaminakis, Siampos \& Kostopoulos , 2015). Also, maintaining meaningful and wellconsidered policies and procedures is a critical component of a strong management system. They are used to establish an organization's internal controls and for ensuring compliance with regulatory standards (Compass Point Nonprofit Services, 2012).

\section{Supervision:}

Supervision is an activity undertaken by someone occupying a formal role within an organization that has (more or less) explicit expectations and accountabilities to both the person being supervised, and the organization which provides the context for the supervisory relationship (Swanson \&Watt, 2011). Supervision can occur in a variety of contexts: supervision of service delivery by supervisees, administrative supervision, supervision of research activities conducted by supervisees, and supervision of individuals mandated by regulatory entities related to disciplinary actions (Chair, Doll, Ellis, Goodyear, Kaslow, McCutcheon, ......., 2014).

\section{Organizational and Management Support:}

To provide support is fundamental if a productive and satisfied staff member is needed. Staff members should be treated as assets, with respect and caring (Nagy \& Vilela, 2015). IM can be a promoter which establishes an attractive workplace for internal customers. 
Management tools for creating a satisfied environment by marketing approaches include: give priority employees in the organization; develop a career widely as a product; strong communication as a major source of satisfaction; improve team working and collaborative activities; provide scholarships and funding for training and research (Isfahani et al., 2012; Susanti et al., 2015).

\section{Training, Advancement and Performance Appraisal:}

Training both physically, socially, intellectually and mentally are very essential in facilitating not only the level of productivity but also the development of personnel in any organization (Olaniyan \& Ojo, 2008). IM focused on continuous improvement of internal customers and their understanding of the organization for which they work will be decisive in the creation of highly competitive and advanced organizations (Paliaga \& Strunje, 2011). Although it is expensive for the organization to spend the money on their internal customers but this investment is positive for the organizations to hold the place in the market (Jehanzeb \& Bashir, 2013).

\section{Organizational Communication:}

It is important for the internal communication process to be part of the organizational culture and entrenched in its values (Shima \& George, 2014).Furthermore, staff awareness of organizational vision, mission and goals would also increase their involvement in management, fostering feelings of belongingness. Above all else, managers' understanding and knowledge of internal marketing is a determining factor in the practice of these activities (Gezen, Akinci, EsatoElu, Parsons \& Sarp, 2007).

6. Empowerment:Many service organizations are attempting to implement the concept of internal marketing. In doing so, organizations have to take cognizance of the need to empower internal customers in order to put such an idea into practice (Papasolomou, 2006).

\section{Job description:}

Job descriptions prevent lawsuits and increase productivity, It clarify and enhance communication between employer and internal customers, and they are critical in supporting nearly every employment action (Kratt, 2015).A good job description functions as a foundation for developing interview questions, carrying out performance evaluations, and setting goals, salary increases, and growth paths. It should be used by 
both employee and manager as a tool for establishing development goals (Kratt, 2015; Ojimba, 2016).

\section{Strategic Rewards and Incentive Systems:}

Undoubtedly, organizations may improve or change their reward systems and put more efficient and effective ones to survive in today's environment (Güngor, 2011). For maximum effectiveness, IM programs should be tightly integrated with overall strategy and reward systems, especially with respect to compensation (Tsai \& Wu, 2011).

\section{Health and Safety Measures:}

A safe and healthy workplace does not happen by chance or guesswork (Safe Work Australia, 2011). School action for safety and health (SASH) (2010) added that having an effective health and safety program can help educational institutions to prevent injuries and illnesses among their internal customers.Proper implementation of internal marketing practices results into satisfied faculty member who perform well and want to stay with the university resulting also into competitive advantage (Shabbir \& Salaria, 2014)

\section{Significance of the Study}

The universities of every country reflect an image of that country through their quality of educational standard. It attracts at national level and foreign investment and thus it generates economic activity. An important implication for practitioners is that internal customers satisfaction is an important (internal) marketing priority and consequently. Furthermore, it promotes economy through generating profits(Shabbir \& Salaria, 2014). As a result of this great effect of internal marketing, this study is geared to study the availability of internal marketing elements among internal customers in academic field.

\section{AIM OF THE STUDY:}

To assess the availability of internal marketing elements among internal customers of the Faculty of Nursing, Port Said University.

\section{Study Objectives:}

1. Assess the availability of internal marketing elements among the teaching staff at the faculty of nursing, Port Said University. 
2. Identify the availability of internal marketing elements among employees at the faculty of nursing, Port Said University.

3. Assess the availability of internal marketing elements among students at the faculty of nursing, Port Said University.

\section{SUBJECTS AND METHOD:}

\section{Study Design \& Setting}

A descriptive research design was used, carried out at the Faculty of Nursing in Port Said University.

\section{Study Sample}

The study populations have included all available internal customers of the faculty $(n=378)$, They divided into three groups:Teaching staff $(n=59)$ included (assistant professor (1), lecturers(26), assistant lecturers (14) and demonstrators (18), administrative staff (employees) ( $\mathrm{n}=68$ ), and nursing students from second, third, and fourth academic years, in addition to the internship students $(n=251)$, after exclusion of the pilot study $(n=41)$ from the entire sample size, with one year experiences at least in the studied faculty.

TOOLS OF DATA COLLECTION:Data were collected by three questionnaire sheets to assess the availability of internal marketing elements among internal customers of the Faculty of Nursing, Port Said University. Internal marketing questionnaire was developed by Hussein (2009) based on Clark (1998); Elsayed (2005). There were some modifications done by the researcher in the light of literature review (Accreditation of Institutions of Higher Education for the Arab Republic of Egypt Guide, 2009) through adding items in different dimensions describing more details about support, empowerment, safety measures, communication, reward and benefits system and training.

Tool (1):Internal Marketing among Nursing Teaching Staff: A questionnaire sheet was used to assess the availability of internal marketing elements among the teaching staff at the Faculty of Nursing, Port Said University.This tool was divided into two parts:Personal and job characteristics part, and Internal Marketing Elements among Nursing Teaching Staff, It was composed of 174 items under 12 dimensions, as following: policy and administration, salary and benefits, supervision, communication, training and advancement, job description, achievement and rewards, institutional 
support, safety measures, scientific research support, administrative support and recognition, and empowerment.

Tool (2):Internal Marketing among Employees: A questionnaire sheet was used to assess the availability of internal marketing elements among the employees at the Faculty of Nursing, Port Said University.This tool was divided into two parts: Personal and Job Characteristics Part and IM Elements among Faculty of Nursing Employees, It was composed of 133 items under 11 dimensions, as following: policy and administration, benefits, supervision, communication, training and advancement, job description, achievement and rewards, institutional support,, safety measures, administrative support and recognition and empowerment.

Tool (3):Internal Marketing among Faculty of Nursing Students: A questionnaire sheet was used to assess the availability of internal marketing elements among the students at the Faculty of Nursing, Port Said University.This tool was divided into two parts:Personal and Job Characteristics Part and Internal Marketing Elements among Nursing Students, It was composed of 173 items under 10 dimensions, as following: policy and administration, benefits, supervision, communication, training and advancement, achievement and rewards, administrative support and recognition, Institutional support, safety measures, and empowerment.

\section{Tool Content Validity and Reliability:}

The Structured Interviewing Questionnairewas tested for content validity by a panel ofeleven experts in the field of community health nursing and public health medicine. The reliability was assured by calculating cronbach's alpha coefficients for each factor, it was high (0.88).

\section{Pilot study:}

A pilot study was undertaken before starting the data collection. It was carried out on 41studied personnel (9 teaching staff, 11 employees and 31 students). It was conducted at the time from 15th April 2015 to 14May 2015. The purpose was to test the applicability and the feasibility of the study tools. Also, it served to estimate the time needed to complete the data collection. In addition to find out any obstacles and problems that might interfere with data collection. The subjects included in the pilot study were excluded from the study subjects. The final form of the tool was formulated and the time needed for completing them was determined. 


\section{Administrative and Ethical Considerations:}

An official permission was obtained from the Faculty of Nursing to obtain the authorization for data collection. The aim of the study was explained to every internal customer before participation, and voluntary participation was emphasized and an oral consent was obtained.

\section{Statistical Analysis}

Data entry and statistical analysis were done using statistical package of social science (SPSS) version 16.0. Data were presented using descriptive statistics in the form of frequencies and percentages for determining the means the standard deviations and correlations for internal marketing elements for the teaching staff, employees and students at faculty of nursing in Port Said University.

\section{Field Work:}

After obtaining the official permission to conduct the study and after finalization of tools, the investigator met with the internal customers individually and explained to them the purpose of the study, the consent of each one were obtained before their participation. Data collection period extended three months from the beginning of May to the end of June 2015. Time needed for filling Questionnaire ranged from 20 to 30 minutes.

\section{RESULTS:}

\section{PART I: Internal Marketing among Nursing Teaching Staff}

Table (1): Personal and job characteristics of the teaching staff at the faculty of nursing, Port Said University. It was found that the mean age of the teaching staff was 32.9 years; the majority of the teaching staff were females (98.3\%); three quarters of the teaching staff was married (76.3\%); they are presented from six different scientific departments; less than half of the studied teaching staff were lecturers $(44.1 \%)$; the mean years of experience among nursing teaching staff was 9.8 years.

Table (2): The availability of internal marketing elements among the teaching staff at the Faculty of Nursing, Port Said University. It was found that more than two thirds $(70.6 \%)$ of the teaching staff was agree that the elements of internal marketing are applied in the faculty.Slightly more than half of teaching staff (52.5\%) was agree that the salary and benefits that are produced by the faculty satisfy their needs. While more than three quarters of them $(76.5 \%)$ was agreed about the communication in the faculty. 
PART II: Internal Marketing among Employees

Table (3): Personal and job characteristics of the employees at the faculty of nursing, Port Said University. It was found that the mean age of the employees was 38.7 years; most of the employees $(70.6 \%)$ were females; $72.1 \%$ of them were married; they are presented ten different departments, $39.7 \%$ of the studied employees were $1^{\text {st }}$ degree of job rank; $11.8 \%$ have administrative positions; the experience duration means of employees participants was 13.1 years.

Table (4): The availability of internal marketing elements among employees at the Faculty of Nursing, Port Said University. It was found that $62.3 \%$ of the employees were agreeing that the elements of IM are applied in the faculty.Only $43.5 \%$ was agreeing that the salary and benefits that are produced by the faculty satisfy their needs. While more than two third of them $(69.1 \%)$ was agreed about the communication in the faculty.

\section{PART III: Internal Marketing among Nursing Students}

Table (5): Personal characteristics of the students at the faculty of nursing, Port Said University. It was found that mean age of students was 21.5 years; $62.9 \%$ of students were females: they are presented three different academic years in addition to internship year.

Table (6): The availability of internal marketing elements among the students at the Faculty of Nursing, Port Said University. It was found that $69.5 \%$ of students were agreeing that elements of IM are applied in faculty. While more than two third (68.2\%) of students was agreeing that benefits that are produced by faculty satisfy their needs. And $72.1 \%$ of them were agreeing about communication in faculty. 
Table (1): Personal and job characteristics of the teaching staff at Port Said' faculty of nursing.

\begin{tabular}{|l|l|l|}
\hline \multirow{2}{*}{ Personal and job characteristics } & \multicolumn{2}{|l|}{ teaching staff (n=59) } \\
\cline { 2 - 3 } & No. & \multicolumn{1}{l|}{ \% } \\
\hline Personal characteristics & \multicolumn{2}{|l|}{} \\
\hline Age (years)Min-Max & $23.0-50.0$ \\
\hline Mean \pm SD & $32.9 \pm 7.2$ \\
\hline GenderMale & 1 & 1.7 \\
\hline Female & 58 & 98.3 \\
\hline Marital statusSingle & 11 & 18.6 \\
\hline Married & 45 & 76.3 \\
\hline Divorced & 3 & 5.1 \\
\hline Occupational characteristics & & \\
\hline SpecialtyNursing Administration & 7 & 11.9 \\
\hline Obstetrics and gynecology nursing & 14 & 23.7 \\
\hline Pediatrics nursing & 8 & 13.6 \\
\hline Community health nursing & 8 & 13.6 \\
\hline Medical and surgical nursing & 18 & 30.5 \\
\hline Psychiatry nursing & 4 & 6.8 \\
\hline Academic rank Demonstrator & 18 & 30.5 \\
\hline Assistant lecturer & 14 & 23.7 \\
\hline Lecturer & 26 & 44.1 \\
\hline Assistant professor & 1 & 1.7 \\
\hline Duration of experience (years)Min-Max & $1.0-25.0$ & \\
\hline Mean \pm SD & $9.8 \pm 6.9$ & \\
\hline
\end{tabular}

Table (2): All elements of internal marketing among teaching staff at Port Said' faculty of nursing.

\begin{tabular}{|c|c|c|c|}
\hline \multirow[b]{2}{*}{ Elements } & \multicolumn{3}{|c|}{ teaching staff $(n=59)$} \\
\hline & Min & $\operatorname{Max}$ & Mean $\pm S D$ \\
\hline Policy and administration & 42.0 & 98.0 & $72.0 \pm 11.4$ \\
\hline Salary and benefits & 20.0 & 78.2 & $52.5 \pm 11.9$ \\
\hline Supervision & 40.0 & 100.0 & $75.1 \pm 13.4$ \\
\hline Communication & 26.7 & 100.0 & $76.5 \pm 13.2$ \\
\hline Training and advancement & 26.7 & 100.0 & $72.8 \pm 16.8$ \\
\hline job description & 20.0 & 100.0 & $72.9 \pm 16.9$ \\
\hline Achievement and rewards & 32.0 & 98.0 & $63.9 \pm 14.9$ \\
\hline Institutional support & 30.0 & 100.0 & $70.9 \pm 13.7$ \\
\hline Safety measures & 32.7 & 100.0 & $72.1 \pm 13.7$ \\
\hline Scientific research support & 26.5 & 100.0 & $73.2 \pm 13.6$ \\
\hline $\begin{array}{lll}\text { Administrative } & \text { support } & \text { and } \\
\text { recognition }\end{array}$ & 28.6 & 100.0 & $71.9 \pm 15.4$ \\
\hline Empowerment & 28.5 & 100.0 & $68.7 \pm 15.6$ \\
\hline Total score $(\%)$ & $n \pm S$ & & $70.6 \pm 12.1$ \\
\hline
\end{tabular}


Table (3): Personal and job characteristicsof the employees at Port Said' faculty of nursing.

\begin{tabular}{|c|c|c|}
\hline \multirow{2}{*}{ Personal and job characteristics } & \multicolumn{2}{|c|}{ employees $(n=68)$} \\
\hline & No. & $\%$ \\
\hline \multicolumn{3}{|l|}{ Personal characteristics } \\
\hline Age (years):Min-Max & \multicolumn{2}{|c|}{$22.0-58.0$} \\
\hline Mean \pm SD & \multicolumn{2}{|c|}{$38.7 \pm 10.2$} \\
\hline Gender:Male & 20 & 29.4 \\
\hline Female & 48 & 70.6 \\
\hline Marital status:Single & 13 & 19.1 \\
\hline Married & 49 & 72.1 \\
\hline Divorced/widow & 6 & 8.8 \\
\hline \multicolumn{3}{|l|}{ Occupational characteristics } \\
\hline Specialty:Technical affair & 31 & 45.6 \\
\hline Purchase affair & 10 & 14.7 \\
\hline Administrative affair & 3 & 4.4 \\
\hline Youth care affair & 2 & 2.9 \\
\hline Postgraduate affair & 2 & 2.9 \\
\hline Library & 3 & 4.4 \\
\hline Financial affairs & 6 & 8.8 \\
\hline Stores & 1 & 1.5 \\
\hline Undergraduate affairs & 7 & 10.3 \\
\hline Salaries & 3 & 4.4 \\
\hline job rank: $1^{\text {st }}$ degree & 27 & 39.7 \\
\hline $2^{\text {nd }}$ degree & 11 & 16.2 \\
\hline $3^{\text {rd }}$ degree & 21 & 30.9 \\
\hline $4^{\text {th }}$ degree or more & 9 & 13.2 \\
\hline Administrative position:Absent & 60 & 88.2 \\
\hline Present & 8 & 11.8 \\
\hline Duration of experience (years): & 31 & 45.6 \\
\hline $10-$ & 19 & 27.9 \\
\hline $20-<30$ & 18 & 26.5 \\
\hline Min-Max & \multicolumn{2}{|c|}{$1.0-29.0$} \\
\hline Mean \pm SD & \multicolumn{2}{|c|}{$13.1 \pm 8.4$} \\
\hline
\end{tabular}

Table (4): All elements of internal marketing among employees at Port Said' faculty of nursing.

\begin{tabular}{|l|c|c|c|}
\hline \multicolumn{1}{|c|}{ Elements } & Min & Max & Mean \pm SD \\
\hline Policy and administration & 35.6 & 95.6 & $63.4 \pm 12.4$ \\
\hline Salary and benefits & 20.0 & 80.0 & $43.5 \pm 15.7$ \\
\hline Supervision & 28.6 & 100.0 & $67.8 \pm 14.9$ \\
\hline Communication & 25.7 & 100.0 & $69.1 \pm 11.9$ \\
\hline Training and advancement & 26.7 & 100.0 & $60.6 \pm 15.4$ \\
\hline job description & 28.0 & 100.0 & $64.0 \pm 15.3$ \\
\hline Achievement and rewards & 22.0 & 100.0 & $56.6 \pm 14.3$ \\
\hline Institutional support & 20.0 & 100.0 & $66.8 \pm 13.4$ \\
\hline Safety measures & 32.7 & 100.0 & $67.1 \pm 13.7$ \\
\hline $\begin{array}{l}\text { Administrative } \\
\text { recognition }\end{array}$ & 20.0 & 100.0 & $66.5 \pm 15.4$ \\
\hline Empowerment & 20.0 & 100.0 & $60.4 \pm 14.4$ \\
\hline Total score (\%): Mean $\mathbf{S D}$ & & $62.3 \pm 11.4$ \\
\hline
\end{tabular}


Table (5): Personal characteristics of students at faculty of nursing in Port Said University.

\begin{tabular}{|l|c|c|}
\hline \multirow{2}{*}{\multicolumn{1}{|c|}{ Personal characteristics }} & \multicolumn{2}{c|}{ Students $(\mathbf{n = 2 5 1})$} \\
\cline { 2 - 3 } & No. & \% \\
\hline Personal characteristics & \multicolumn{2}{c|}{$19.0-24.0$} \\
\hline Age (years):Min-Max & \multicolumn{2}{c|}{$21.5 \pm 1.1$} \\
\hline Mean+SD & 93 & 37.1 \\
\hline Gender:Male & 158 & 62.9 \\
\hline Female & 102 & 40.6 \\
\hline Academic year:2 $^{\text {nd }}$ & 61 & 24.3 \\
\hline $3^{\text {rd }}$ & 59 & 23.5 \\
\hline $4^{\text {th }}$ & 29 & 11.6 \\
\hline Internship year & 59 \\
\hline
\end{tabular}

Table (6): All elements of internal marketing among students at Port Said' Faculty of Nursing.

\begin{tabular}{|l|l|l|l|}
\hline \multicolumn{1}{|c|}{ Elements } & Min & Max & Mean \pm SD \\
\hline Policy and administration & 22.2 & 100.0 & $70.5 \pm 19.3$ \\
\hline Benefits & 28.0 & 100.0 & $68.2 \pm 20.1$ \\
\hline Supervision & 24.4 & 100.0 & $70.7 \pm 18.6$ \\
\hline Communication & 20.0 & 100.0 & $72.1 \pm 18.0$ \\
\hline Training and advancement & 20.0 & 100.0 & $69.8 \pm 19.7$ \\
\hline Achievement and rewards & 20.0 & 100.0 & $70.7 \pm 19.4$ \\
\hline Institutional support & 20.0 & 100.0 & $68.7 \pm 20.2$ \\
\hline Safety measures & 20.0 & 100.0 & $68.5 \pm 20.8$ \\
\hline Administrative support and recognition & 20.0 & 100.0 & $68.5 \pm 21.4$ \\
\hline Empowerment & 20.0 & 100.0 & $69.2 \pm 20.8$ \\
\hline \multicolumn{2}{|l}{ Total score (\%): Mean \pm SD } & $69.5 \pm 18.6$ \\
\hline
\end{tabular}

\section{DISCUSSION:}

A better understanding of internal marketing and the study of its prevalence in Universities would go a long way in ensuring efficient delivery of services (Qayum \& Sahaf, 2013). Internal marketing allows organizations to establish an organizational vision for managers, provide training and development for internal customers, enhance motivation, inspiration, retain internal customers, and tightly integrated with overall strategy and reward systems, especially with respect to compensation (Tsai \& Wu, 2011). So, this study was conducted to assessing the availability of internal marketing elements among teaching staff, employees and students at the Faculty of Nursing, Port Said University. 
Regarding the total availability of total internal marketing elements at the faculty of nursing, Port Said University, the findings indicated that availability of internal marketing elements among teaching staff is the highest total of availability, followed by students and employees. Also, the finding revealed that the communication element is the highest one among all internal customers (teaching staff, employees and students), followed by supervision and scientific research support among teaching staff, supervision and safety measures among employees and supervision and achievement and rewards among students. This finding supported byTsai (2014) who concluded that communication channels between the managers and staff should be strengthened to clearly convey the vision and goals to frontline employees.And Falender and Shafranske (2012) who clarified that organization has to establish the supervisory relationship by satisfying the roles, tasks, responsibilities of supervisee and supervisor. This may be due to the advanced method of teaching that the faculty use, which help in increasing the availability of communication and supervision elements. Also,Chepkwony and Oloko (2014)concluded that management should ensure that reward system is effective enough and competitive to influence internal customers to work harder

Whereas, the lowest total of availability element of internal marketing among all internal customers of the faculty is the benefits. This may be due to limited resources of the small and newly Port Said University lead to low level of benefits.The current study findings indicated that the majority of teaching staff and employees stated that the faculty administration does not provide a nursery in the faculty, no means of transportations for teaching staff and no opportunity for foreign secondment for employees, which about half of the students of the faculty asserted that faculty administration provides means of transportations, housing of expats, place for students break as cafeteria. This finding is in congruent with Chepkwony and Oloko (2014) who recommended that internal customer's benefits is not competitive enough. While, Ramos (2015) stated that organizations should update internal customer' fringe benefits to keep abreast with the current trends on internal customer needs and motivation. This would mean that Port Said faculty of nursing need to develop new forms of benefits to increase level of satisfaction of the internal customers. 
In general, understanding internal customers' wants and needs and selling internally responsibility goals would make external efforts in developing a responsible strategy much more likely to succeed (Sanchez-Hernandez \& Grayson, 2012). So finally, managers need to be more proactive trying to introduce the marketing function in human capital issues. Understanding internal customers' wants and needs and selling internally responsibility goals would make external efforts in developing a responsible strategy much more likely to succeed (Sanchez-Hernandez \& Grayson, 2012).

\section{CONCLUSION:}

It was concluded that availability of internal marketing elements at the faculty of nursing, Port Said University is moderately fulfilled. The highest mean score of internal marketing availability was among the teaching staff followed by students and employees. The most available element of the internal marketing among the three categories (teaching staff, employees and students) is the communication element, followed by supervision and scientific research support among teaching staff, supervision and safety measures among employees and supervision followed by achievement and rewards among students. Whereas, the lowest available element is the benefits among teaching staff, employees and students.

\section{RECOMMENDATIONS:}

The faculty administration has to develop an internal marketing strategy and take needed measures towards increasing the availability of internal marketing elements among their internal customers (teaching staff, employees and students) through: improving all attributes of benefits, pay, rewards, empowerment, support, and training and safety measures. And energize all attributes of supervision and communication. Also faculty administration has to regularly assess the availability of internal marketing elements among their internal customers.

\section{REFERENCES:}

Accreditation of institutions of higher education for the Arab republic of Egypt, (2009).Guide of Accreditation of institutions of higher education for the Arab republic of Egypt.

Berry, L. (1981). The employees as customers. Journal of retail banking, 3(3), $25-28$. 
Boukis, A., Kaminakis, K., Siampos, A. \& Kostopoulos, I. (2015). Linking internal marketing with customer outcomes, Marketing Intelligence \& Planning, 33(3), 394 - 413. Available online at http://dx.doi.org/10.1108/MIP-02-2014-0024

Byju, K. (2013). Internal Marketing: Employee does matter. Global journal of management and business studies, 3(5), 519-524. Available online at http://www.ripublication.com/gjmbs.htm

Chair, C., Doll, B., Ellis, M., Goodyear, R., Kaslow, N., McCutcheon, S., ..... (2014). Guidelines for clinical supervision in health service psychology. Available at https://www.apa.org/about/policy/guidelines

Chepkwony, C. \& Oloko, M. (2014). The relationship between rewards systems and job satisfaction, a case study at teachers' service commission- Kenya. European journal of business and social sciences, 3(1), 59-70. Available at http://www.ejbss.com/recent.aspx

Compass point nonprofit services (2012).Nonprofit fiscal policies \& procedures: A template and guide. Available online athttps://www.compasspoint.org/sites/default/files/

Conduit, J. \& Mavondo, F. (2001). How critical is internal customer orientation to market orientation. Journal ofBusiness Research, 51(1), 11-24. Available online athttp://www.sciencedirect.com/

Falender, C. \& Shafranske, E. (2012). Clinical Supervision: A CompetencyBased Approach. (2 $2^{\mathrm{ST}}$ ed.), American psychological association, USA.

Fogel, E. (2016).The importance of internal marketing. Available online at http://www.elainefogel.net/

Galpin, T. (1997). Making strategy work. The journal of business strategy, $18(1), 12-14$.

Gezen, A., Akinci, F., EsatoElu, A., Parsons, A. \& Sarp, N. (2007). An evaluation of the opinions of hospital employees regarding the contribution of internal marketing to the application of total quality management in Turkey. Health marketing quarterly (The Haworth Press), 24(3/4), 167-188. 
Gungor, P. (2011). The relationship between reward management system and employee performance with the mediating role of motivation: A quantitative study on global banks. Procedia Social and Behavioral Sciences, 24(2011), 1510-1520. Available at http://ac.els-cdn.com/

Hashem, T. \& Al-nsour, I. (2012). The effect of internal marketing on internal service quality in Jordanian banks. Asian Journal of Business and Management Sciences, 2(2), 8-18. Available online at http://www.ajbms.org/index.php

Hogg, G., Carter, S., \& Dunne, A. (1998). Investing in people: internal marketing and corporate culture. Journal of marketing management, 14(1), 879-895.

Isfahani, A., Yarali, M. \& Kazemi, A. (2012). Analyzing the influence of Internal Marketing on Employee happiness case study: Nilou Tile Company, Isfahan. International journal of academic research in business and social sciences, 2(9), 167178. Available online athttp://hrmars.com/

Jehanzeb, K. \& Bashir, N. (2013). Training and development program and its benefits to employee and organization: A conceptual study. European journal of business and management, 5(2), 243-253. Available online at www.iiste.org

Kokemuller, N. (2015). What is the meaning of internal marketing?. Available online at http://www.ehow.com/info

Kratt, M. (2015).The importance of job descriptions and why your practice needs them. Available online at http://www.dentistryiq.com/ content/diq/en/index.html

Lings, I. (2000). Internal marketing and supply chain management", Journal of services marketing, 14(1), 27-43. Available online athttp://www.emeraldinsight.com/

Martinez, M., Stinson, J. \& Jubenville, C. (2011). Internal marketing perceptions in intercollegiate athletics and their influence on organizational commitment. Journal of issues in intercollegiate Athletics, (4), 171-189. Available at http://csrijiia.org/old/documents/publications/

Minar, T., Sarwari, S. \& Salam, M. (2008). Internal marketing: a strategic tool to achieve inter-functional co-ordination in the context of a manufacturer of industrial equipment. Daffodil International University, Journal of business and economics, 3(1),173-187.Available online at http://www.academicstar.us/index.asp 
Nagy, J. \& Vilela, M. (2015).Providing support for staff and volunteers. Available online at http://ctb.ku.edu/

Ogunnaike, O., Oyeniyi, O. \& Adeniji, A. (2012). Internal marketing practices and job satisfaction: Evidence from a Nigerian University setting. Broad research in accounting, negotiation, and distribution, 3(3), 18-30. Available online athttps://doaj.org/

Ojimba, E. (2016).The importance of job descriptions. Available online at http://www.salary.com/author/erisa-ojimba

Olaniyan, D.A. \& Ojo, L.B. (2008). Staff training and development: A vital tool for organizational effectiveness. European Journal of Scientific Research, 24(3), 326-331. Available online at http://www.eurojournals.com/ejsr.htm.

Paliaga, M. \& Strunje, Z. (2011). Research of implementation of internal marketing in companies in the republic of Croatia. Economic research-Ekonomska istraživanja, 24(1), 107-121.Available online at http://www.tandfonline.com/toc/rero20/24/1?nav=tocList\#

Papasolomou, I. (2006). Can internal marketing be implemented within bureaucratic organizations?. International journal of bank marketing, 24(3), 194-212. Available at http://www.emeraldinsight.com/loi/ijb

Qayum, M.N. \& Sahaf, M.A. (2013). Internal Marketing: A pre-requisite for employee satisfaction in Universities. International journal of business and management invention (IJBMI), 2(5), 2319-2328. Available online atwww.ijbmi.org.

Ramos, J. (2015). Internal marketing (IM) dimensions and organizational commitment (OC) of universal banks' employees.Proceedings of the Second Asia-Pacific Conference on Global Business, Economics, Finance and Social Sciences (AP15Vietnam Conference), Danang, Vietnam, 10-12 July 2015.

Ružić, E., Paliaga, M. \& Benazić, D. (2016). Measuring the relationship between internal marketing and job satisfaction, motivation and customer orientation in utility (municipal) services. Available online athttp://markopaliaga.com/wpcontent/

Safe Work Australia (2011).How to manage work health and safety risks, code of practice. Available online at www.safeworkaustralia.gov.au 
Sanchez- Hernancez, I. \& Grayson, D. (2012).Internal marketing for engaging employees on the corporate responsibility journey. Intangible Capital, 8(2): 275307.http://dx.doi.org/10.3926/ic.305

School action for safety and health (SASH), (2010). Promoting injury and illness prevention programs for California's School employees. Available online at www.dir.ca.gov/chswc/sash

Shabbir, J. \& Salaria, R. (2014). Impact of internal marketing on employee job satisfaction: An investigation of higher education institutes of Pakistan.Journal of marketing management, 2(2), 239-253.

Shima, B. \& George, B. (2014). Strategies for the development of internal marketing orientation in the private high education institutions in Albania. Academic journal of interdisciplinary studies,3(3), 393.Available online athttp://www.mcser.org/journal/index.php/ajis/ issue/view/71

Susanti, E., Sule, E. \& Sutisna, H. (2015). The Impact of internal and external service quality, A Case study among lecturers and students. Mediterranean journal of social sciences, $6(5, \quad$ S5), 77-83. Available online athttp://www.mcser.org/journal/index.php/mjss/article/view/ 7879/7545

Swanson, C. \& Watt, S. (2011). Good Practice in the supervision \& mentoring of postgraduate students, it takes an academy to raise a scholar. The Centre for Leadership in Learning, McMaster University. Available online at https://cll.mcmaster.ca/resources/pdf/ Supervision\%20

Tsai, Y. \& Wu, S. (2011). Using internal marketing to improve organizational commitment and service quality. Journal of advanced nursing, 67(12), 2593-2604.

Tsai, Y. (2014). Learning organizations, internal marketing, and organizational commitment in hospitals. BMC health service research, 14(152), 1-8. Available at http://download.springer.com/

Varun, K. \& Indu, B. (2015). Internal marketing: A tool for success of Hotel industry. Advances in Management, 8(4), 55-60. Available online athttps://www.questia.com/library/journal/1P3-3648669621/ 


\section{التسـويـق الــاخلـي لكليـة التمـريـض بـجـامسعة بـورسـعيد}

على ضيف الله عبدالسلام أبوسليمان_أ.د / نعمات محمد السيد_أ.د/ سناء عبدالعظيم ابراهيم33 ـد/رشا ابراهيم 4 عنانى اماجستبر/دارة التمريض - كلبة التصريض- جامعة كفرالثيخ/ 2 أستاذ ادارة التصريض - كلية التصريض - جامعة

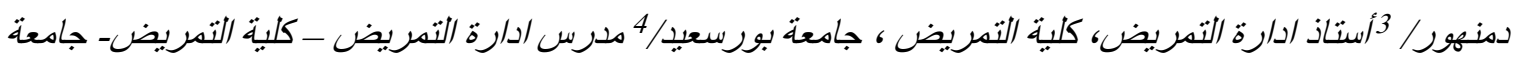
بورسعيد

\section{الخلاصة}

هدف الدر اسـة هو تقييم مدى اتاحيـة عناصر التسويق الداخلي بكلية التمريض /جامعة بورسعيد. وقد أجريت دراسـة وصفية شارك فيها جميع المتاح من هيئة التدريس وموظفين وطلاب الكلية خـلال العام الدراسي 2016/2014، ولقد شـارك فى البحث عدد 378 يمثلون الفئات الثناث ، تم استخدام ثلاثثة استنيانات لقياس مدى تو افر عناصر التسويق الداخلي بين أعضاء هيئة التدريس وموظفين وطلاب الكلية. ولقد كثفت النتائج عن أكثر عناصر التسويق الداخلي إتاحسة بين أعضاء هيئة التدريس و الموظفين و الطلاب هو التواصل، يليه الإتر اف ودعم البحث العلمي بين هيئة التدريس،

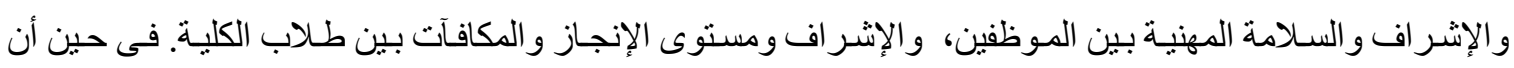
المنافع كانت الأقل إتاحة لكل من هيئة التدريس و الموظفين و الطلاب. نستخلص من الإس اسـة أن مدى اتاحسة عناصر

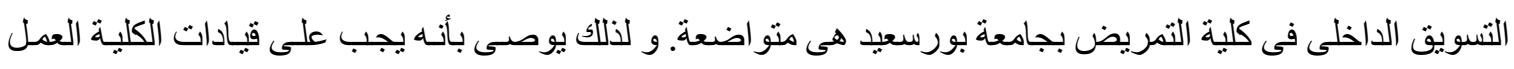
على اعداد استر اتيجية للتسويق الداخلي بالكلية.

الكلمات الـمرشــدة :التسويق الداخلي، المستهلك الداخلي، الهيئة التدريسية، الطلاب، الموظفين 